\title{
Subchronic Oral Exposure to Prometryne Changes Relations of Blood Biochemistry Indicators in Mice
}

\author{
Domagoj Đikić ${ }^{1}$, Vesna Benković ${ }^{1}$, Anica Horvat-Knežević ${ }^{1}$, \\ Gordana Brozović ${ }^{\text {, Nada Oršolić }}{ }^{1}$, Oscar P. Springer ${ }^{1}$ \\ ${ }^{1}$ Faculty of Science, University of Zagreb, Department of Animal Physiology, Biology Division, Zagreb, Croatia \\ ${ }^{2}$ University Hospital for Tumors, Zagreb, Croatia
}

Received July 2, 2008

Accepted December 15, 2008

\begin{abstract}
Prometryne is a methylthio-s-triazine herbicide used for the control of annual broadleaf and grass weeds in many cultivated plants. Significant traces are documented in the environment, mainly waters, soil and plants used for human and domestic animal nutrition. The aim of this study was to investigate whether prometryne, administered orally, could induce changes in metabolic patterns and cause cell damage in specific organs of exposed mice. Three different doses of prometryne $(185,375,555$ $\mathrm{mg} \cdot \mathrm{kg}^{-1}$ ) were given per os repeatedly every $48 \mathrm{~h}$, in a subchronic in vivo experimental design. After 28 days (14 doses), the correlations between the basic blood biochemistry indicators were analyzed (LDH, GGT, ALP, creatinine, ALT, AST). The increase in GGT and decrease in creatinine were the most distinct effects. LDH and ALP were increased, but rather explicitly in different dosage groups. ALT and AST did not change significantly, indicating that liver damage was milder than expected. Significant correlations between specific enzymes in renal tissue were lost in exposed groups. The correlations between muscle tissue specific enzymes were significant as a result of prometryne toxicity. Disbalance in relations between the serum indicators under study indicates that prometryne might have a myotoxic and nephrotoxic potential and the potential to affect enzymes and molecules important in normal metabolic pathways of bioenergetic physiology.
\end{abstract}

Prometryne, nephrotoxicity, myotoxicity, hepatotoxicity, CBA

Prometryne is a pre-emergency and post-emergency selective systemic, methylthio-striazine herbicide. It is often used for the control of annual broadleaf and grass weeds in many cultivated plants. Its herbicide effects in target plants are based on the inhibition of photosynthetic transport electrons at the photosystem II receptor site and inhibition of oxidative phosphorylation (EPA-IRIS 2001).

Prometryne and its residues can be traced in significant concentrations in rural areas and third world countries where it is still used in considerable quantities. Even though banned in some European countries, large areas of Australia, Canada, China, India and USA are still treated with this herbicide (EPA-IRIS 2001; Kamrin and Montgomery 2000). Prometryne or 1,3,5-triazine-2,4-diamine ( $N, N^{\prime}$-bis (1-methylethyl)-6-(methytio)-1, 3, 5-triazine- 2, 4,-diamine is persistent in waters and up to 50 days in soil (DT $=50 \mathrm{~d}$ ) (Hua et al. 2006; Leh et al. 2005; Muller and Britz 1982; Gordienko 1977; Fiveland 1977). Prometryne is present in significant concentrations even in the air near production or application sites (Schumann et al. 1990). For decades, contaminated drinking water has been the main source of exposure; however, significant amounts reach humans or domestic animals through nutrition plants (Bardalaye and Wheeler 1985; Dubenetskaia et al. 1981; Reifenstein and Pank 1975). Other routes of entry in non-target organisms are through traces and residues in cow and human milk (Balduini et al. 2003; Křivánková et al. 1989).

In spite of an increased number of scientific papers on prometryne in the last few years, there is only a small number of publications indicating its toxic effects (Statistics on prometryne 2008; EPA-RED 1996). Furthermore, within the re-evaluation of the effective substances of pesticides in the EU guideline 91/414/EEC, prometryne has not been classified as Appendix I chemical (Directive 91/414/EEC 1991). The majority of experiments describing

Address for correspondence:

Đikić Domagoj, PhD

Department of Animal Physiology, Biology Division,

Faculty of Science, University of Zagreb, Rooseveltov trg 6

10000 Zagreb, Croatia

Phone: +38514877747, +38514877753

E-mail: magistardjikic1@yahoo.com

http://www.vfu.cz/acta-vet/actavet.htm 
prometryne toxicity were conducted in vitro or ex vivo (Kurebayashi 2005; Leh et al. 2005; Temperli et al.1966). Toxic effects of prometryne and other methylthio-s-triazine published so far deal with immunohaematotoxicity or leukocyte genotoxicity (Đikić et al. 2009; Giurgea et al.1981; Gzhegotskii 1968). Prometryne partition coefficient of $\mathrm{pK}_{\mathrm{o}}$ $=3.5$ (Kamrin and Montgomery 2000) and non-polarity of its molecular structure (mol. $\left.{ }_{\mathrm{w}}^{\mathrm{w}} \mathrm{t}=241.4\right)$, point to its affinity toward tissues high in the lipid content.

To expand the existing limited knowledge of physiological changes that prometryne causes in vivo concerning misbalance of metabolism, the focus of this study was to compare the relations of the activity of basic enzymatic blood biomarkers. The aim of this experiment was the detection of physiological changes, defects of various organ systems, and changes in metabolic pathways caused by prometryne after repeated subchronic exposure to three different doses of prometryne administered in vivo by means of suitable screen laboratory diagnostic tools (James 1993; Evans 1996). Our results may serve as a risk assessment model for the poisoning of humans and domestic animals by this widely used triazine herbicide.

\section{Materials and Methods}

Animals and treatments

The experiments were carried out according to the guidelines in force in Croatia (Law on the Welfare of Animals, NN\# 19, 1999) and in compliance with the Guide for the Care and Use of Laboratory Animals, DHHS Publ. \# (NIH) 86-123 and OECD Guidelines for subchronic (28 days) toxicity testing in rodents (OECD 1995). Inbred CBA mice, from the mouse colony of the Faculty of Science, University of Zagreb were used. The animals were maintained on a pellet diet (Pliva, d.d, Croatia) and water was provided ad libitum. The animals were maintained under $12: 12 \mathrm{~h}$ light-dark regime. Within each group $(\mathrm{n}=10,5 \propto+5 \hat{\jmath})$ mice received low, medium and high doses of prometryne $\left(\mathrm{C}_{10} \mathrm{H}_{19} \mathrm{~N}_{5} \mathrm{~S}\right)$, CAS No. 7287-19-6, EPA Reg. No. 9779-297 (tech. grade 95\%, Herbos dd, Sisak). The control group $(\mathrm{n}=10,59+5 \hat{\jmath})$ received no prometryne. The prometryne doses were 185,375 and $555 \mathrm{mg} \cdot \mathrm{kg}^{-1}$, respectively. The medium dose represents $1 / 10$ of the $\mathrm{LD}_{50 \text { (mice) }}=3750 \mathrm{mg} \cdot \mathrm{kg}^{-1}$ (EPA-RED 1996). The dose of $185 \mathrm{mg} \cdot \mathrm{kg}^{-1}$ which is $1 / 20$ of the $\mathrm{LD}_{50}$ and two-fold lower than the medium dose used was selected as the first effective dose $\left(\mathrm{ED}_{10}\right)$ recognized through pilot tests. The dose of $555 \mathrm{mg} \cdot \mathrm{kg}^{-1}$ was selected as the highest effective dose without lethal toxicity $\left(\mathrm{LD}_{10}\right)$ during 28 days and also recognized through pilot tests. The metabolic study of Maynard et al. (1999) showed that the majority of the absorbed prometryne is metabolized or excreted within $48 \mathrm{~h}$. To avoid overdose through bioaccumulation ( $\log \mathrm{PK}_{\mathrm{o} / \mathrm{w}}=3.5$; Kamrin and Montgomery 2000), mice were given prometryne per os every $48 \mathrm{~h}$ during 28 days, prepared as a corn oil suspension, at the volume of $0.2 \mathrm{ml}$ per animal. The control group received the same volume of corn oil following the same schedule. To avoid false changes influenced by excessive blood loss caused by frequent sampling, the blood samples were collected on the $28^{\text {th }}$ day of the experiment by intra-cardiac puncture described in EMPReSS, SOP (Standard Operating Procedure) (Green et al. 2005 but also see http://empress.har.mrc.ac.uk) and processed to enzyme assay protocols. Control group data were within the normal reference ranges at the end of the experiment and they were the reference point for comparison with the treated groups (Matsusawa et al. 1993; James 1993). The whole experiment was repeated three times.

Enzyme assays

The experiment and biochemistry analysis were conducted according to the recommendations of the IFCC methods in enzymology and done with commercial kits (Herbos dd, Sisak) on the Hitachi 717 automatic analyzer (Hitachi, Japan). Briefly, the activity of LDH-P (E.C.1.1.1.27) was measured from non-haemolysed blood serum, at $37^{\circ} \mathrm{C}, 340$ $\mathrm{nm}$ piruvate to lactate continuous turnover reaction measurement reaction. GGT (E.C. 2.3.2.2), was measured from non-haemolysed blood serum at $37^{\circ} \mathrm{C}, 405 \mathrm{~nm}$, substrate y-glutamil-3carboxy-4 nitroanilid, IFCC modified SzaszRosalki method. ALP (E.C.3.1.3.1.) was measured from non-haemolysed blood serum, at $37^{\circ} \mathrm{C}, 405 \mathrm{~nm}$, and substrate 4-nitrophenilphosphate. AST (E.C. 2.6.1.1.) and ALT (E.C.2.6.1.2.) were measured from non-haemolysed serum, at $37^{\circ} \mathrm{C}, 340 \mathrm{~nm}$. Creatinine concentrations were measured with the method of alkaline picrate complex on $492 \mathrm{~nm}$.

Statistical analysis

Statistical analyses were performed using Statistica 5.0 software (StatSoft, Tulsa, USA). Each sample was characterized by enzyme activity level considering the mean ( \pm standard deviation of the mean). The unit of measurement was the animal. Multiple comparisons between groups were done by means of ANOVA on logtransformed data in order to normalize the distribution and to equalize the variances. Post-hoc analysis was conducted by Scheffé and Duncan tests to establish differences between the groups. The level of significance was set at $p \leq 0.05$ and in tables and figures the differences are marked according to the LSD system. The Pearson correlation coefficient (coefficient $r$ ) was assessed between all variables. All measured variables were tested two-sidedly to find significant correlation dependence links between them and significant changes that occur as a delineation of dose-response relationship. Only significant $r$ values that were found after correlation analysis are shown in the results which were considered significant at $p \leq 0.05$ and $p \leq 0.01$, respectively (Evans 1996). 


\section{Results}

There were no significant changes in the body weight of treated or control mice throughout the experiment (Table 1).

The analysis of the liver and kidney weights showed no significant changes in the weight of the liver but a significant decrease in the weight of the kidneys $(p \leq 0.05)$ in animals exposed to the highest $\left(555 \mathrm{mg} \cdot \mathrm{kg}^{-1}\right)$ dose of prometryne (Table 1).

Table 1. Body weight of mice throughout the experiment and weights of the liver and kidney in the control group and groups of animals treated with three different doses of prometryne

\begin{tabular}{|c|c|c|c|c|c|c|c|c|}
\hline \multirow{4}{*}{$\begin{array}{l}\text { "Body Weight } \\
1^{\text {st }} \text { day (g) }\end{array}$} & \multicolumn{8}{|c|}{ Prometryne dose } \\
\hline & \multicolumn{2}{|c|}{$\begin{array}{l}0 \mathrm{mg} \cdot \mathrm{kg}^{-1} \\
(\text { Control) }\end{array}$} & \multicolumn{2}{|c|}{$185 \mathrm{mg} \cdot \mathrm{kg}^{-1}$} & \multicolumn{2}{|c|}{$375 \mathrm{mg} \cdot \mathrm{kg}^{-1}$} & \multicolumn{2}{|c|}{$555 \mathrm{mg} \cdot \mathrm{kg}^{-1}$} \\
\hline & \multicolumn{2}{|c|}{$\mathrm{X} \pm \mathrm{SD}$} & \multicolumn{2}{|c|}{$\mathrm{X} \pm \mathrm{SD}$} & \multicolumn{2}{|c|}{$\mathrm{X} \pm \mathrm{SD}$} & \multicolumn{2}{|c|}{$\mathrm{X} \pm \mathrm{SD}$} \\
\hline & $21.55 \pm$ & $2.57^{\mathrm{NS}}$ & $21.83 \pm$ & $3.11^{\mathrm{NS}}$ & $21.47 \pm$ & $3.56^{\mathrm{NS}}$ & $21.57 \pm$ & $2.21^{\mathrm{NS}}$ \\
\hline $14^{\text {th }}$ day $(\mathrm{g})$ & $21.57 \pm$ & $2.83^{\mathrm{NS}}$ & $22.08 \pm$ & $2.88^{\mathrm{NS}}$ & $21.62 \pm$ & $3.16^{\mathrm{NS}}$ & $20.86 \pm$ & $2.17^{\mathrm{NS}}$ \\
\hline \multirow{4}{*}{$\begin{array}{l}28^{\text {th }} \text { day }(\mathrm{g}) \\
\text { Organ weight } \\
\text { Kidney }(\mathrm{g}) \\
\text { Liver }(\mathrm{g})\end{array}$} & $21.65 \pm$ & $3.05^{\mathrm{NS}}$ & $22.4 \pm$ & $2.88^{\mathrm{NS}}$ & $21.4 \pm$ & $3.11^{\mathrm{NS}}$ & $21.83 \pm$ & $3.11^{\mathrm{NS}}$ \\
\hline & \multicolumn{2}{|c|}{$\mathrm{X} \pm \mathrm{SD}$} & \multicolumn{2}{|c|}{$\mathrm{X} \pm \mathrm{SD}$} & \multicolumn{2}{|c|}{$\mathrm{X} \pm \mathrm{SD}$} & \multicolumn{2}{|c|}{$\mathrm{X} \pm \mathrm{SD}$} \\
\hline & $0.16 \pm$ & $0.01^{\mathrm{b}}$ & $0.16 \pm$ & $0.02^{b}$ & $0.15 \pm$ & $0.02^{\mathrm{b}}$ & $0.13 \pm$ & $0.01^{\mathrm{a}}$ \\
\hline & $1.21 \pm$ & $0.15^{\mathrm{NS}}$ & $1.23 \pm$ & $1.15^{\mathrm{NS}}$ & $1.26 \pm$ & $0.13^{\mathrm{NS}}$ & $1.12 \pm$ & $0.11^{\mathrm{NS}}$ \\
\hline
\end{tabular}

"Body weight was measured every second day of the experiment, for simplicity only three measurements are shown.

a,b Means with different superscripts within one row are significantly different $(p \leq 0.05)$

NS Means are not significantly different within the row

The activity of blood serum enzymes ( $\mu$ kat) and significant differences between all groups of mice exposed to three different doses of prometryne and the control group are shown in Figs 1 to 6.

The level of LDH activity was increased (1.25 fold, $p \leq 0.05)$ within the low $\left(185 \mathrm{mg} \cdot \mathrm{kg}^{-1}\right)$ and middle $\left(375 \mathrm{mg} \cdot \mathrm{kg}^{-1}\right)$ dosage groups compared to the control. In the highest dose group the LDH activity was the same as in the control group (Fig. 1).

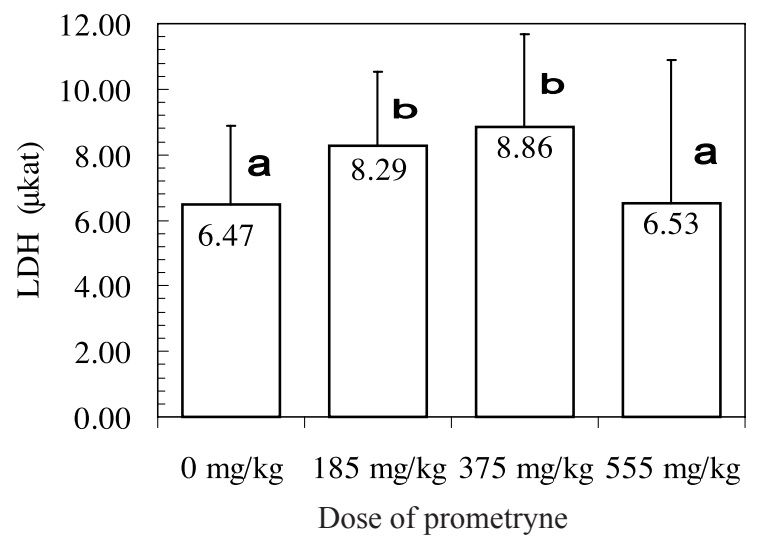

Fig. 1. Activity of blood lactate dehydrogenase (LDH) in mice repeatedly treated with three different doses of prometryne in a 28 day subchronic toxicity study. The number within the bar is the mean, lines on bars are standard deviation. 
The activity of GGT increased proportionally to the dose. The highest GGT activity increase was noted in the highest dose group, characterized by 3.6 fold $(p \leq 0.05)$ increase compared to the control (Fig. 2).

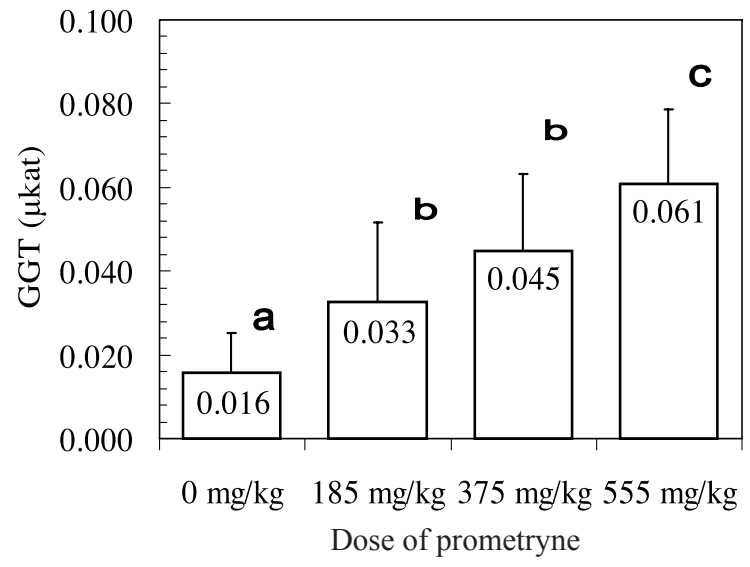

Fig. 2. Activity of blood gamma glutamyl transferase (GGT) in mice repeatedly treated with three different doses of prometryne in a 28 day subchronic toxicity study. The number within the bar is the mean, lines on bars are standard deviation.

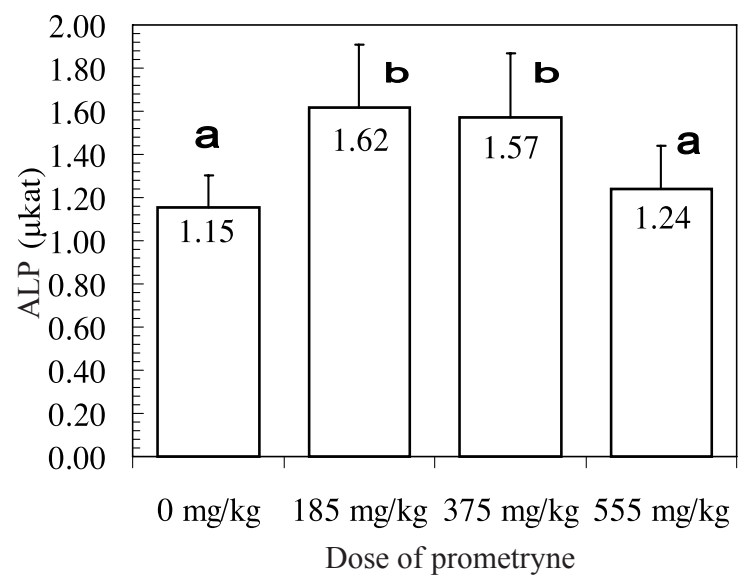

Fig. 3. Activity of blood alkaline phosphatase (ALP) in mice repeatedly treated with three different doses of prometryne in a 28 day subchronic toxicity study. The number within the bar is the mean, lines on bars are standard deviation.

The activity of ALP followed the same pattern as LDH. It increased 1.4 fold $(p \leq 0.05)$ at the lowest and medium dose compared to control. In the group that received the highest dose, the activity of ALP remained at the same level as in the control group (Fig. 3). The concentration of creatinine $\left(\mu \mathrm{mol} \cdot \mathrm{l}^{-1}\right)$ was the only variable that decreased proportionally with the dose. Creatinine concentration decreased 1.7 fold $(p \leq 0.05)$ in the animals challenged with the highest dose compared to the control (Fig. 4). 


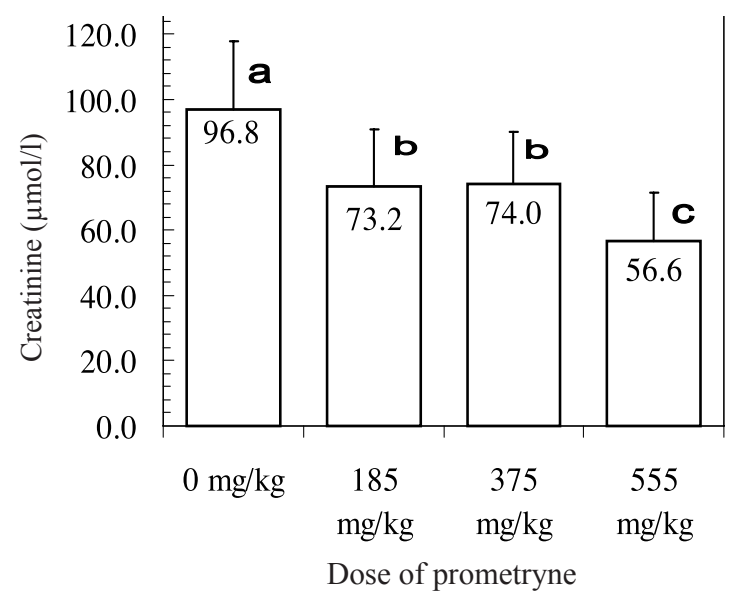

Fig. 4. Concentration of blood creatinine in mice repeatedly treated with three different doses of prometryne in a 28 day subchronic toxicity study. The number within the bar is the mean, lines on bars are standard deviation.

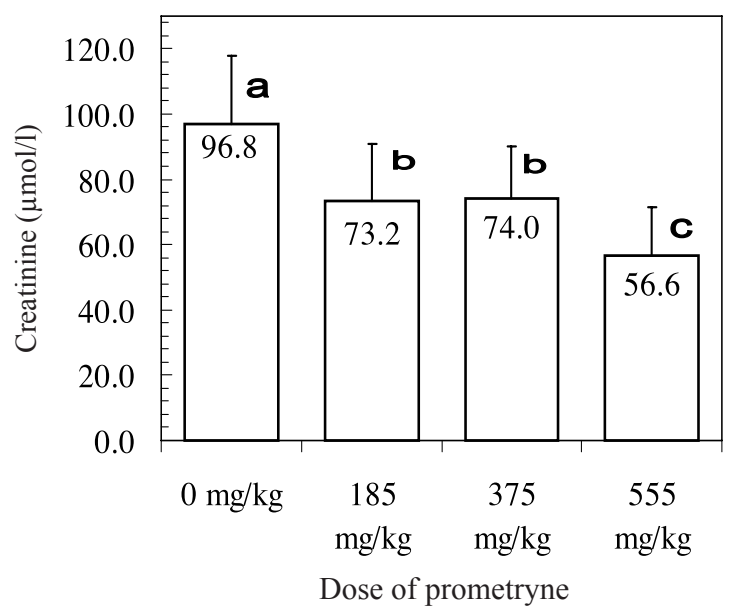

Fig. 5. Activity of blood aspartate aminotransferase (AST) in mice repeatedly treated with three different doses of prometryne in a 28 day subchronic toxicity study. The number within the bar is the mean, lines on bars are standard deviation.

AST of all the measured indicators showed no significant change among all treated groups and between the treated groups and the control group (Fig. 5). ALT changed slightly but significantly $(p \leq 0.05)$ in the highest dose (Fig. 6).

Correlation coefficients ( $r$ values) are shown in Table 2. First three rows contain the dependent variables in the control group and show the loss of correlation between the enzyme activity levels due to prometryne poisoning. The last two rows show the new significant correlations between the variables that appear as a consequence of poisoning.

In control animals, the high, positive correlation dependence $(p \leq 0.05)$ was noted between the activity of GGT, ALP and AST, and between ALP and AST. With the lowest dose group, this relationship changed. Prometryne exposure caused the disappearance of 


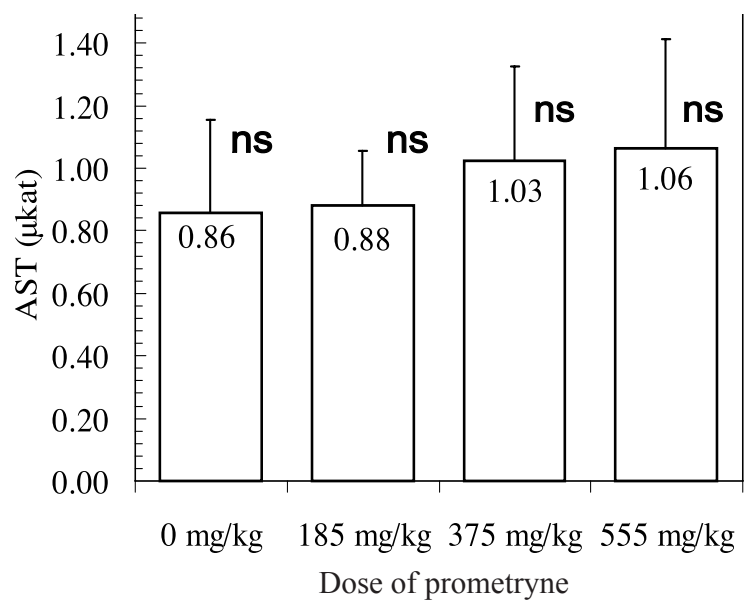

Fig. 6. Activity of blood alanine aminotransferase (ALT) in mice repeatedly treated with three different doses of prometryne in a 28 day subchronic toxicity study. The number within the bar is the mean, lines on bars are standard deviations.

Table 2. Pearson product-moment correlation coefficient $(r)$ between enzyme activities in the control group and groups of animals treated with three different doses of prometryne

\begin{tabular}{|l|c|c|c|c|}
\hline \multirow{2}{*}{$\begin{array}{l}\text { \# Corelated enzyme } \\
\text { activities }\end{array}$} & \multicolumn{3}{|c|}{ Prometryne dose } \\
\cline { 2 - 5 } $\begin{array}{l}\text { ALP vs. GGT } \\
\text { AST vs. GGT }\end{array}$ & $0.680^{*}$ & 0.082 & $375 \mathrm{mg} \cdot \mathrm{kg}^{-1}$ & $555 \mathrm{mg} \cdot \mathrm{kg}^{-1}$ \\
\cline { 2 - 5 } $\begin{array}{l}\text { AST vs. ALP } \\
\text { Creatinine vs. LDH } \\
\text { Creatinine vs. ALP }\end{array}$ & $0.582^{* *}$ & -0.363 & -0.175 & 0.208 \\
\cline { 2 - 5 } & $0.803^{*}$ & $0.687^{*}$ & 0.108 & 0.143 \\
\cline { 2 - 5 } & 0.101 & $0.615^{* *}$ & 0.441 & -0.195 \\
\hline
\end{tabular}

\#All measured variables were tested for correlations between activities in each dose group but only significant links between the enzymes $(* p \leq 0.01$ and $* * p \leq 0.05)$ are presented.

First three rows present the loss of correlation due to prometryne, and the last two rows present the links between the variables that become significantly dependent with the application of prometryne.

the correlation ties between the activity of GGT, ALP and AST, whereas the AST vs. ALP correlation was decreased but still significant $(p \leq 0.05)$. The lowest dose of prometryne also caused correlation linking $(p \leq 0.05)$ between the concentration of creatinine and LDH activity. Disappearance of all significant correlations was noted in the animals that were exposed to the medium and high doses of prometryne and all connections between enzyme activities that existed in the control group were lost as a direct consequence of prometryne toxicity.

\section{Discussion}

There are no published data so far that show changes in the activity of major serum enzymes caused by subchronic exposure to prometryne. The enzymes measured are recommended by OECD standards and are usually connected to physiology of the liver, kidneys and skeletal muscles (Kaneko et al. 1997; OECD 1995). The study was designed 
to simulate the normal entry route (oral) of environmentally present prometryne, and repeated the dosage every $48 \mathrm{~h}$ to maintain a constant bioavailable concentration, avoiding overdose or bioaccumulation within the tissues as previously shown by Maynard et al. (1999). The enzyme activities and their correlations were determined in a point of time (after 28 days) and a remarkable metabolic misbalance between exposed and control group was noted with each dose, respectively. The most pronounced changes were the increase in GGT activity and the decrease in the concentration of creatinine. In rodents, the highest GGT concentrations are usually found in the brush border cells of the proximal convoluted tubules of the kidneys but also in the pancreas and liver. The kidney concentration of GGT in rodents is 200 times higher than in the hepatic tissue. Normal plasma GGT activity is usually very low in rodents but becomes markedly increased after severe nephrotoxic damage. The decrease in blood creatinine could either be connected to the disability of muscle tissue to produce it due to toxic myopathies or due to the nephrotoxic damage that increased nephron porosity for such small molecule which is then released in urine (Evans 1996).

The significant increase in LDH and ALP dose was noted in low and medium but not in the highest dose. This trend of activity of LDH and ALP at the highest dose could be explained by the fact that at the low and medium dose the physiology of the organs that are producing the enzymes was not disturbed up to complete arrest of their synthesis. Therefore, the higher blood level was the consequence of toxic stress at the low and medium doses, whereas the highest dose was potent enough to stop the synthesis of LDH and ALP, which was than reflected in the general decrease of activity. When observing the recorded activity of the highest dose group as a time-dynamic process, it could be assumed that the highest dose passed through the higher activity (as in the low and medium doses) a few days earlier, before the impairment of synthesis. From the day when the impairment in synthesis occurred. Until the $28^{\text {th }}$ day, the activity started to decrease and approached values similar to the control. Should the activity of LDH and ALP be measured after the $28^{\text {th }}$ day it would probably decrease even further, probably even below the activity of the control group. LDH is specific to muscle cells but could also point to hepatic damage. ALP is non-specific and associated to bile canaliculi, sinusoid surfaces of the liver but also kidneys. The rise in the ALP level in the low and medium doses points out that all those organs were affected at the level of plasma membrane where the lipid bilayer was distressed enough to release higher amounts of this transport enzyme in blood.

In order to confirm that the increase of GGT, LDH and ALP is due to hepatotoxic damage, their increase should be accompanied by a parallel increase in AST and ALT (Edge et al. 2006; Gaskill et al. 2005; Gopal and Rosen 2000). In our experiment, slight, mainly nonsignificant changes in AST and ALT and their proportion after prometryne poisoning, point to lesser liver damage which is in agreement with other authors (Edge et al. 2006; Gaskill et al. 2005; Gopal and Rosen 2000). The significant correlations between the enzymes should therefore be observed in the direction of renal damage (GGT, ALP and creatinine), and possible muscular (creatinine and LDH) damage (Carter et al. 2008; Antonelli et al. 2007). Unchanged liver weight and significant loss of kidney weight in poisoned animals and their control at the end of subchronic exposure period give further support to that explanation. Surprisingly, even when experimentally administered at high doses (higher than environmentally present), our results indicate that the original molecule of prometryne does not severely disrupt liver physiology or its biotransformation capacity as expected for a poisonous herbicide that ends up as xenobiotic in mammalian organism. The in vivo study of Maynard et al. (1999) demonstrated that orally administered prometryne was biotransformed to over 30 different metabolic residues that are detected in blood, faeces and urine after $48 \mathrm{~h}$. Until now it is not known what toxic potential those biotransformation products have in mammalian organisms regarding organ integrity and metabolic balance. 
It has been documented that in some cases xenobiotic metabolites could be more poisonous than the original molecule. As pointed out by our results, the prometryne biotransformation metabolites reach and damage other organs (muscle or kidneys) to a higher extent than the prometryne itself, which is primarily in contact with, and degraded by the liver whose physiology and cell integrity remains less disturbed than downstream organs. Taking into account the position of the analysed enzymes in metabolic pathways, it could be assumed that the partial inhibition of oxidative phosphorylation that prometryne causes in plants as herbicide, also took place in the mammalian organism. Disappearance of significant correlations between enzymes in the animals that were exposed to prometryne was a direct consequence of prometryne toxicity. Such results represent a new and unexpected finding that direct future analyses of prometryne toxicity to renal toxicity and myotoxicity in the field of in vivo physiology damage by environmentally present triazine compounds and residues.

\section{Změny biochemických ukazatelů v krvi myší po subchronickém perorálním podávání prometrynu}

Prometryn je methylthio- s- triazinový herbicid užívaný pro potlačení celoročně rostoucích plevelných listnatých dřevin a travin, které narušují pěstování mnoha kulturních plodin. V životním prostředí byla zjištěna stopová množství tohoto pesticidu, především ve vodách, půdách a rostlinách určených pro lidskou spotřebu nebo jako zdroj výživy domácích zviŕrat. Cílem této studie bylo zjistit zda perorálně aplikovaný prometryn může navodit metabolické změny s následným poškozením buněk specifických orgánů exponovaných myší. Tři různé dávky prometrynu $\left(185,375,555 \mathrm{mg} \cdot \mathrm{kg}^{-1}\right)$ byly opakovaně podávány per os každých 48 h, pro navození subchronického účinku in vivo. Po 28 dnech (14 dávek) byly stanoveny základní krevní biochemické ukazatele (LDH, GGT, ALP, kreatinin, ALT, AST) a korelovány s fyziologickými hodnotami. Nejvíce patrnou změnou bylo zvýšení GGT a snížení kreatininu. Hodnoty LDH a ALP byly zvýšené, ale spíše explicitně v různých skupinách lišících se dávkou prometrynu. Vzhledem k tomu, že se hodnoty ALT a AST významně nezměnily, lze usoudit, že míra jaterního poškození nedosahovala předpokládané úrovně. U pokusných skupin nebyly signifikantní změny u enzymů charakterizujících renální tkán̆. Specifické enzymy svalové tkáně byly signifikantně změněny vlivem toxického účinku prometrynu.

\section{Acknowledgements}

The authors thank the Ministry of Science, Education and Sports of the R. Croatia for the grant and project support (Grant no. 119-00000001255). Also we wish to show our deep appreciation to Mrs Marija Potočić for technical support.

\section{References}

Antonelli AC, Torres GAS, Soares PC, Mori CS, Sucupira MCA, Ortolani EL 2007: Ammonia poisoning causes muscular but not liver damage in cattle. Arq Bras Med Vet Zootec 59: 8-13

Balduini L, Matoga M, Cavalli E, Seilles E, Riethmuller D, Thomassin M, Guillaume YC 2003: Triazinic herbicide determination by gas chromatography-mass spectrometry in breast milk. J Chromatogr B 794: 389-395

Bardalaye PC, Wheeler WB 1985: Capillary gas chromatographic determination of prometryne and its degradation products in parsley. J Assoc Off Anal Chem 68: 750-753

Carter WO, Bull C, Bortolon E, Yang L, Jesmok J, Gundel RH 2008: A murine skeletal ischemia-reperfusion model differential pathology in BALB/C and DBA/2N mice. J Appl Physiol 85: 1676-1683

Đikić D, Židovec-Lepej S, Remenar A, Horvat-Knežević A, Benković V, Lisičić D, Sajli L, Springer O 2009: The effect of prometryne on subchronically treated mice evaluated by SCGE assay. Acta Biol Hung 60: 35-43

Directive 91/414/EEC 1991: The plant protection products directive 'The authorisations directive' was adopted by the Council of Ministers on 15 July 1991 and published on 19 August 1991 (OJ L230, ISSN 0378 6978).

Dubenetskaia MM, Patent RL, Voitik NP, Voinova IV, Krasnaia SD 1981: Nutritive value of carrots grown using the herbicide prometryne. Vopr Pitan 6: 50-51 
Edge K, Chinoy H, Cooper RG 2006: Serum alanine aminotransferase elevations correlate with serum creatine phosphokinase in myiositis. Rheumatology (Oxford) 45: 487-488

EPA-RED 1996: Reregistration eligibility decision-prometryn. Office of prevention, pesticides and toxic substances (750 BW). EPA 738-R-95-033: 1-171.

EPA-IRIS 2001: Integrated risk information system-prometryn. EPA CASRN 7287-19-6.

Evans GO 1996: Animal clinical chemistry-a primer for toxicologist. Taylor and Francis Press Ltd. UK, 207 p.

Fiveland TJ 1977: Residues of linuron and prometryne in carrots and decomposition in soil in Southern and Northern Norway. Forsk Fors Landbruket 28: 345-363

Gaskill CL, Miller LM, Mattoon JS, Hoffmann WE, Burton SA, Gelens HCJ, Ihle, SL, Miller JB, Shaw DH, Cribb AE 2005: Liver histopathology and liver serum alanine aminotransferase and alkaline phosphatase activities in epileptic dogs receiving Phenobarbital. Vet Pathol 42: 147-160

Giurgea R, Orsa M, Bucur N 1981: Immunological reactions of Wistar rats following administration of atrazine and prometryne. Arch Exp Veterinarmed 35: 811-815

Gordienko NI 1977: Hygienic establishment of the maximum permissible concentration of the herbicide, prometryne, in soil. Gig Sanit 1: 22-25

Gopal DV, Rosen HR 2000: Abnormal findings on liver function tests-interpreting results to narrow the diagnosis and establish a prognosis. Postgrad Med 107: 100-102, 105-109, 113-114

Green E, Georgios V, Koutos G, Heena V, Blake A, Weekes J, Hancock JM 2005: EMPReSS-European mouse phenotyping resource for standardized screens. Bioinformatics 21: 2930-2931

Gzhegotskii MI, 1968: Changes in the peripheral blood under the acute and chronic action of anti-Gramineae herbicides which act via the roots. Gig Tr Prof Zabol 12: 42-43

Hua WY, Bennett ER, Maio XS, Metcalfe CD, Letcher RJ 2006: Seasonality effects on pharmaceuticals and s-triazine herbicides in wastewater effluent and surface water from the Canadian side of the upper Detroit River. Environ Toxicol Chem 25: 2356-2365

James RW 1993: The relevance of clinical pathology to toxicology studies. Comp Haemat Int 3: 190-195

Kamrin MA, Montgomery JH 2000: Agrochemical and pesticide desk reference. CD-ROM. Chapman and Hall CRC net BASE. Int. ed.

Kaneko JJ, Harvey JW, Bruss ML 1997: Clinical biochemistry of domestic animals. Academic Press, 789 p.

Křivánková L, Boček P, Tekel J, Kovačicová J 1989: Isotachophoretic determination of herbicides prometryne, desmetryne, terbutryne and hydroxy-derivatives of atrazine and simazine in extracts of milk. Electrophoresis 10: $731-734$

Kurebayashi H 2005: In vitro metabolism of ametryne and prometryne by human liver microsomes and human cytochrome p450 isoforms. Drug Metab Rev 6: 195-196

Leh B, Zinko B, Narat M, Marinsek-Logar R 2005: Monitoring of genotoxicity in drinking water using in vitro comet assay and Ames test. Food Technol Biotechnol 43: 139-146

Matsusawa T, Nomura M, Unno T 1993: Clinical pathology reference ranges of laboratory animals. Working group II, nonclinical safty ealuation subcomittee of the Japan pharmaceutical manufactures assotiation. J Vet Med Sci 55: 351-362

Maynard MS, Brumback D, Itterly W, Capps T, Rose R 1999: Metabolism of [(1)(4)C] prometryn in rats. J Agric Food Chem 47: 3858-3865

Muller F, Britz M 1982: Regulation of prometryne in the soil. Gig Sanit 8: 68-70

Nagano K, Umeda Y, Nishizawa T, Ikawa N, Arito H, Yamamoto S, Fukushima S 2007: Thirteen-week inhalation toxicity of carbon tetrachloride in rats and mice. J Occup Health 49: 249-259

OECD (Organization of economic cooperation and developments) 1995: Repeated dose 28-day oral toxicity study in rodents. In: OECD Guideline 407 for the testing of chemicals. OECD, Paris, pp 1-8.7

Prometryne Statistics 2008: http://www.gopubmed.org/GoMeshPubMed/gomeshpubmed/?tool=HotTopicDirect \&termAl $=$ mesh $\% 2311400$

Reifenstein H, Pank F 1975: Triazine residues in medicinal plants. Pharmazie 30: 391-393

Schumann G, Garche W, Girenko D 1990: Studies for the assessment of the herbicide prometryne in the air. Z Gesamte Hyg 36: 375-377

Temperli K, Turler H, Ercegovich CD 1966: A mode of action of pesticides I. Incorporation of S triazines (Cyanuric acid and prometryne) into bacterial nucleic acid. Z Naturforsch (B) 21: 903-904 